\title{
Establishment of an in vitro micropropagation protocol for Cantua volcánica (Polemoniaceae): a potential ornamental plant of Peru.
}

\author{
Establecimiento de un protocolo de micropropagación in vitro de Cantua volcánica \\ (Polemoniaceae): una planta con potencial ornamental de Perú
}

Fiorella Medina Medina ${ }^{1}$, Herbert Lazo Rodríguez ${ }^{1 *}$

\begin{abstract}
Cantua volcánica (Polemoniaceae) is a species endemic to Arequipa, Peru. This plant, which has an ornamental potential, is endangered by habitat loss due to anthropogenic pressures and climate change. A protocol was developed for in vitro micropropagation using nodal explants, allowing its massive propagation in vitro. For the establishment stage, $1 / 2 \mathrm{MS}$ was determined to be the best culture medium. In the proliferation stage, the growth regulator balance that showed the highest survival rate was MS + IBA 1 $\mathrm{ppm}+\mathrm{BA} 0.5 \mathrm{ppm}$. Different combinations of NAA-AIB were tested for rooting; MS + NAA 0.005 ppm + IBA 0.005 ppm was determined as the best medium. In the last stage, $65 \%$ of in vitro plants were acclimatized using vermiculite as substrate and irrigating with 50\% Hoagland mineral solution.
\end{abstract}

Key words: Cantua volcánica, micropropagation, shoot proliferation.

\section{RESUMEN}

Cantua volcánica (Polemoniaceae) es una especie endémica de Arequipa, Perú, con potencial ornamental que se halla amenazada por la disminución de su hábitat debido a presiones antropogénicas y cambio climático. Por lo que se elaboró un protocolo, que utiliza nudos de ésta planta como explantes permitiendo su propagación masiva in vitro. El establecimiento de explantes, determinó como mejor medio 1/2 MS. En la fase de multiplicación el balance hormonal (IBA-BA, IBA-kinetina), se determinó como mejor medio de multiplicación $M S+I B A 1$ ppm + BA 0,5 ppm. La fase de enraizamiento con distintas combinaciones de ANA-AIB, determinó como mejor medio MS+ ANA 0.005 ppm + AIB 0.005 ppm. En la fase de aclimatación se logró aclimatar un $65 \%$ de vitroplantas utilizando como sustrato vermiculita y regadas con solución mineral de Hoagland a la mitad de su concentración.

Palabras clave: Cantua volcanica, micropropagación, proliferación de nudos.

\section{Introduction}

Human activity is causing progressive biodiversity degradation. Consequently a great number of plant species are disappearing before being identified or having their properties evaluated (Iriondo 2001). Therefore, in order to save the floristic richness it is important to protect these species. (Ranganathan and Uthayasooriya 2016). The most effective and efficient strategy for conservation is habitat protection; however, it is unlikely that more than $4 \%$ of a geographic area will be protected (Keshavachandran and Peter 2008). Hence it is important to complement in situ methods through ex situ techniques to facilitate better understanding of the physiological and biochemical characteristics of the stored material and to provide propagules for their reintroduction to the ecosystem (Iriondo 2001). Conventional methods of vegetative propagation are slow and expensive in some cases, which leads to the use of more sophisticated techniques such as in vitro micropropagation since they can be carried out throughout the year and allow high proliferation rates (Suárez 1993). The use of genetic resources of native species would increase the public assessment of natural resources (Negrin and Zalba 2012), so cultivating native plants in public and private areas is a way to show the value of floristic elements and spread their use (parks, gardens and pots).

\footnotetext{
1 Laboratorio de Fisiología y Biotecnología Vegetal, Universidad Nacional San Agustín de Arequipa, Perú

* Corresponding author: hlazor@unsa.edu.pe
}

Fecha de Recepción: 01 agosto, 2017.

Fecha de Aceptación: 08 mayo, 2018.

DOI: http://dx.doi.org/10.4067/S0718-34292018005000501. Publicado en línea: 16-agosto-2018. 
Cantua volcanica (Polemoniaceae) is a species endemic to Arequipa, Peru; it is an herbaceous plant with ornamental potential, as it has showy blue-violet flowers (Fig. 1A) and grows between 2200-3200 m elevation. Its distribution is restricted to the Chili Basin and the foot of the Misti volcano (Porter and Prater 2008). Due to its habitat loss, climatic changes, low seed viability, insect attack and anthropogenic intervention, population decline is observed. However, there are no published studies that indicate the current state of its conservation.

Therefore, this study aims to establish a protocol for massive micropropagation of $C$. volcanica and to obtain propagules by in vitro culture techniques, which will serve for the conservation of this species.

\section{Materials and Methods}

The study was performed from July 2016 to May 2017 at the Laboratory of Plant Physiology and Biotechnology of the Faculty of Biological Sciences at the Universidad Nacional de San Agustín de Arequipa.

Plant material. Wild plants of Cantua volcanica (10 to $20 \mathrm{~cm}$ ) were collected in Characato, Arequipa, Peru, within a radius of approximately $100 \mathrm{~m}$ around the following coordinates: $16^{\circ} 27^{\prime} 55.6^{\prime \prime} \mathrm{S} 71^{\circ} 28^{\prime} 45.5^{\prime \prime} \mathrm{W}$ and $2464 \mathrm{~m}$ elevation. Representative botanical samples were sent to the Peruvian Southern Herbarium (HSP) for taxonomic determination.
Surface sterilization stage. The explants were obtained from the first, second and third nodes of each branch (Olesen and Fonnesbech 1975). They were washed in distilled water with Tween $20(100 \mu \mathrm{l}$ per $100 \mathrm{ml})$ for $10 \mathrm{~min}$, then the explants were disinfected by immersion in $70 \%$ ethanol for $1 \mathrm{~min}$ and $20 \mathrm{~min}$ in a $10 \%$ sodium hypochlorite solution (commercial bleach $4.63 \%$ ), then all explants were rinsed 3 times in sterile distilled water for 5 min each time.

Establishment stage. The explants were seeded under aseptic conditions in nutritive medium ( 1 explant per flask). Two culture media were tested determine the most suitable medium; a MS basal medium (Murashige and Skoog 1962) and a half strength MS medium (1/2 MS); both were supplemented with $3 \%(\mathrm{w} / \mathrm{v})$ sucrose. The media were adjusted to $\mathrm{pH} 5.7$ prior to addition of agar-agar $0.8 \%$ (w/v) and sterilized at $121^{\circ} \mathrm{C}$ and $1 \mathrm{Atm}$ pressure for 20 minutes. The explants were cultured under a photoperiod of $16 \mathrm{~h}$ light, with an intensity of 792 Lux (Philips TL-D 36W/865 fluorescent tubes), at $23^{\circ} \mathrm{C}$. After three weeks the survival rate was evaluated by counting live and dead explants.

Proliferation stage. Two treatments were performed to determine the appropriate growth regulator combination for the proliferation of shoots:

-BA-IBA: Benzyladenine 1ppm and indole-3-butyric acid $0.5 \mathrm{ppm}$

-Kin-IBA: Kinetin 2 ppm and indole-3-butyric acid 0.5 ppm
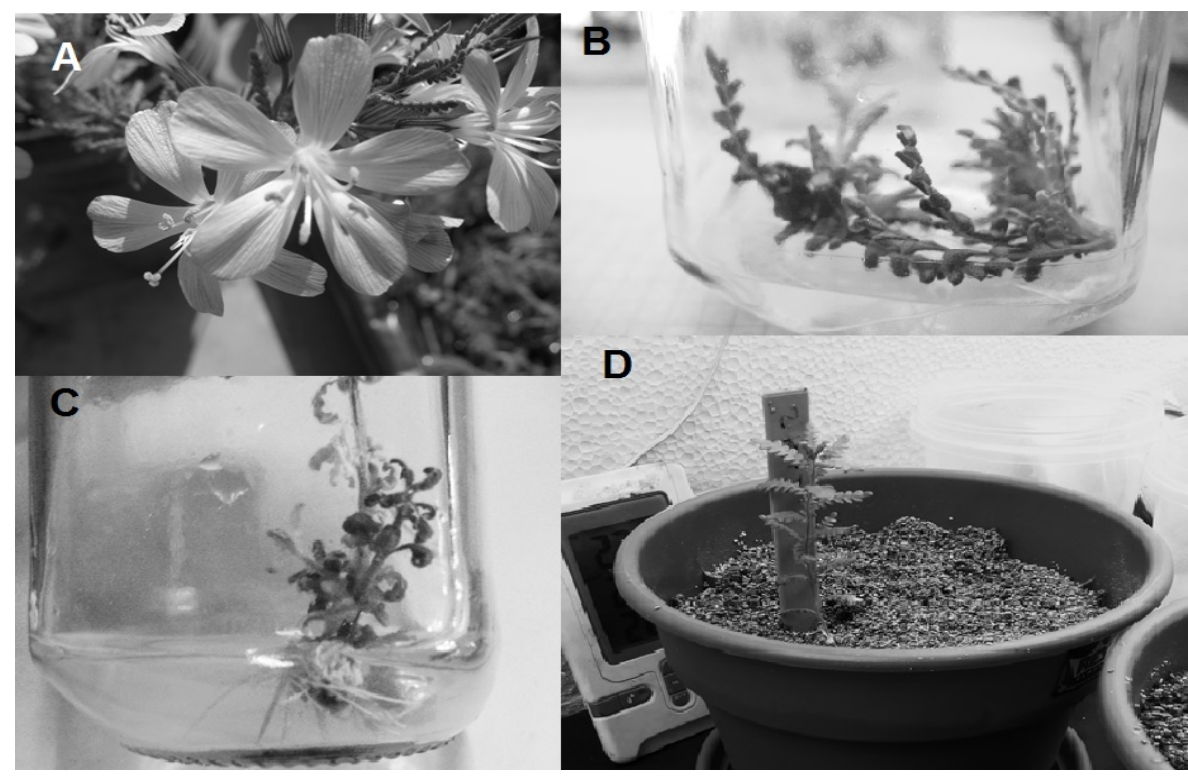

Figure 1: Micropropagation in Cantua volcanica (A) Flowers of C. volcanica, (B) Multiple shoot formation from a nodal explant, (C) Root formation, (D) Acclimated plant. 
Then the following treatments were applied to determine the best balance between BA and AIB:

T1: control (MS basal medium)

T2: MS + IBA $1.5 \mathrm{ppm}$

T3: MS + IBA $1 \mathrm{ppm}+\mathrm{BA} 0.5 \mathrm{ppm}$

T4: MS + IBA $0.5 \mathrm{ppm}+\mathrm{BA} 1 \mathrm{ppm}$

T5: MS + IBA $1.5 \mathrm{ppm}$

After 3 weeks a subculture was performed and after 6 weeks the number and size of shoots produced were evaluated.

Rooting stage. In vitro plants with 8 weeks of culture were used to perform the following treatments:

$\mathrm{T} 1=\mathrm{MS}+\mathrm{NAA} 0.001 \mathrm{ppm}$ and IBA $0.01 \mathrm{ppm}$

$\mathrm{T} 2=\mathrm{MS}+\mathrm{NAA} 0.005 \mathrm{ppm}$ and IBA $0.005 \mathrm{ppm}$

$\mathrm{T} 3=\mathrm{MS}+\mathrm{NAA} 0.01 \mathrm{ppm}$ and IBA $0.001 \mathrm{ppm}$

After four weeks, the number of roots per plant was evaluated.

Acclimatization stage. Rooted in vitro plants were carefully washed with distilled water to remove the remains of agar and transplanted into small plastic pots containing autoclaved vermiculite. Plants were watered to field capacity with 50\% Hoagland solution (Hoagland and Arnon 1950) and hermetically sealed with clear plastic cups. Then plants were placed under artificial illumination of $950 \mathrm{Lux}\left(16 \mathrm{~h} / 8 \mathrm{~h}\right.$ photoperiod) and $22-23{ }^{\circ} \mathrm{C}$ with relative humidity $34 \%$. After a week, 10 holes were made in the plastic cups. In the third week the plastic cups were partially uncovered. Then in the fourth week, the plastic cups were removed and in the fifth week the plants were moved to the greenhouse. In the sixth week, plants were transplanted to pots containing a mixture of sand, moss and agricultural soil (2: 1: 1). At the end of this process the survival rates were evaluated and expressed in percentages.

Statistical analysis. For the establishment stage, differences of survival rates between two culture medium (MS y 1/2MS) were determined by applying the Student's t test $(\mathrm{p}<0.01)$. Raw data was transformed with the formula $\sqrt{ }(x+1)$. Thirty replicates were performed per treatment making 60 experimental units, (E.U) each of which corresponds to an explant in $20 \mathrm{ml}$ of nutrient medium.

For the multiplication stage two experiments were carried out. The first one determines differences of survival rates between Kin-IBA and BA-IBA by applying the $\mathrm{t}$-Student test $(\mathrm{p}<0.01)$. Sixty four explants were planted, making a total of $128 \mathrm{E}$. U. In the second experiment, a CRD was applied to establish the best balance between BA-IBA, 18 replicates were planted per treatment, making 90 E.U.

For the rooting stage, a CRD was applied and the number of roots determined. 16 replicates were made, making a total of 48 experimental units. In the two lasts designs the recorded data was subjected to ANOVA variance analysis and Tukey's specificity test $(\mathrm{p}<0.05)$. All data were processed using the software STATISTICA 7.

\section{Results and Discussion}

Establishment stage. Figure 2 shows that explants cultured on MS basal medium had a lower survival rate (6.6\%) than explants cultured on $1 \frac{1}{2}$ MS medium (83.3\%), with a highly significant difference $(\mathrm{p}<0.01)$. The explants in the MS basal medium showed browning and oxidation. Begonia venosa, Hevea brasilensis and Musa AAB,

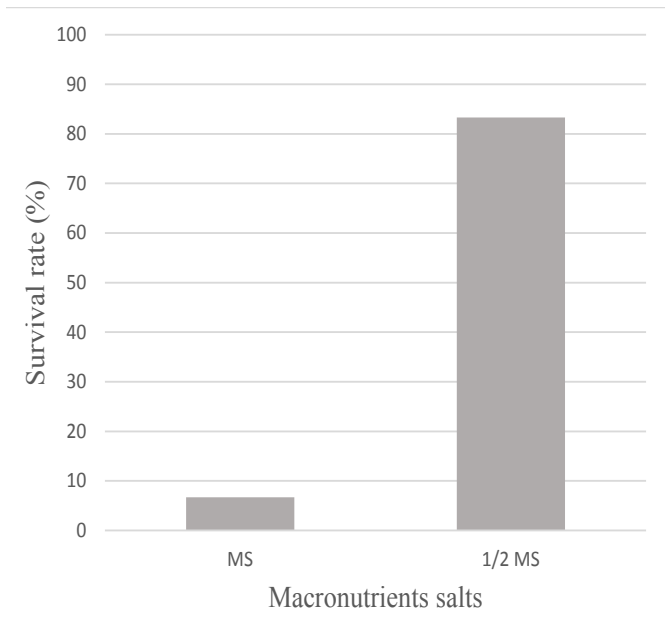

Figure 2: Effects of the MS salt concentration on the survival rate of $C$. volcanica explants (values are expressed as percentages, $\mathrm{n}=30$ ) MS: (Murashige Skoog basal medium). 
were in the same situation and the browning produced by oxidative stress was reduced when it was cultured on $1 / 2$ MS medium as well as $1 / 4$ MS medium (a quarter of salt concentration). (Azofeifa 2009).

Proliferation stage. The best combination of growth regulators was BA-IBA (Fig. 1B, 3) with a higher survival ratio of $65.6 \%$ compared to the Kin-IBA treatment, which decreased the survival rate $(28.1 \%)$ significantly $(\mathrm{P}<0.05)$. However this response is contrary to what is described for Emblica officinalis, Arachis hypogaea, Syzygium cumini, Olea europaea and Gyrinops versteegii (Hidayat, 2011;
Rahman et al 2012) who found that Kin-IBA treatments were better than BA-IBA treatments.

Figure 4 shows the shoot regeneration response to the growth regulators BA-IBA There were significant differences $(p<0.05)$ between the different treatments. The one that induced the greatest number of shoots per node was treatment 3 (BA $0.5 \mathrm{ppm}+$ IBA 1 ppm). The best response of shoot regeneration has been reported in many species with cytokinin concentration lower than auxin. However in this study the opposite relation was found, related to its physiological state in vitro. (Parveen and Shahzad 2014).

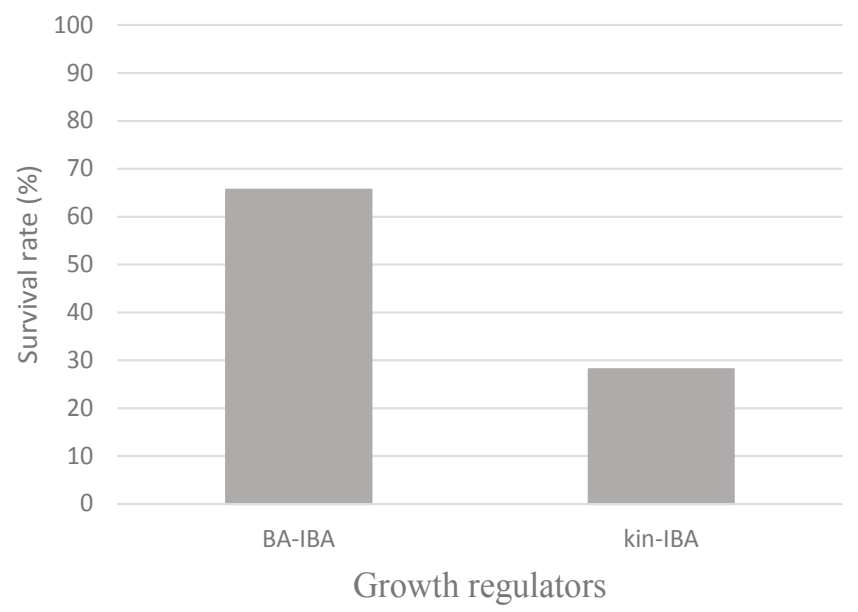

Figure 3: Effects of the BA-IBA and Kin-IBA treatments on the survival rate of $C$. volcanica explants (values are expressed as percentages, $\mathrm{n}=64$ ) BA: Benzyladenine; Kin: Kinetin; IBA: indole butyric acid

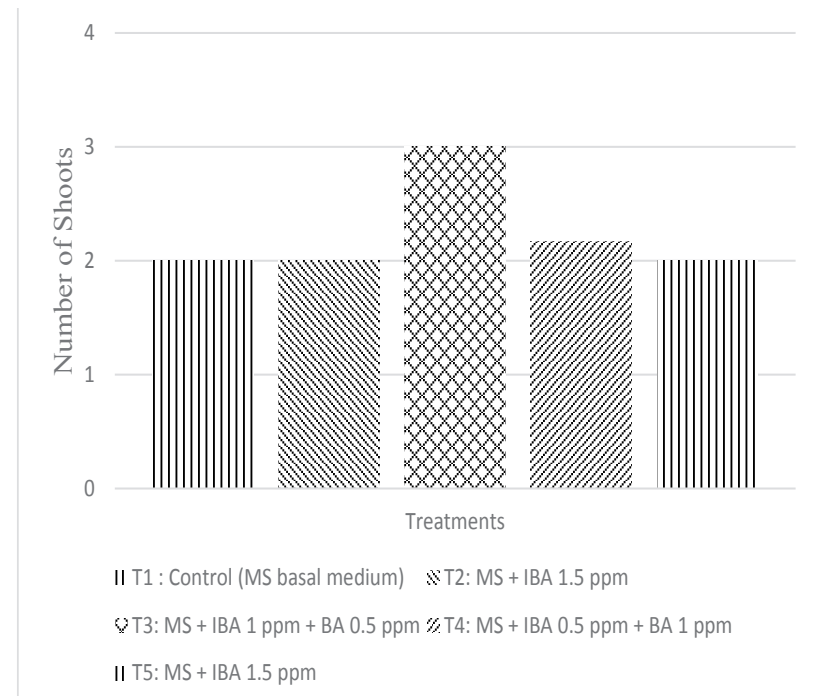

Figure 4: Effects of BA-IBA treatments on the number of shoots per explant of $C$. volcanica (values are expressed as percentages, $\mathrm{n}=18$ ) BA: Benzyladenine; IBA: indole butyric acid; ppm: parts per million 


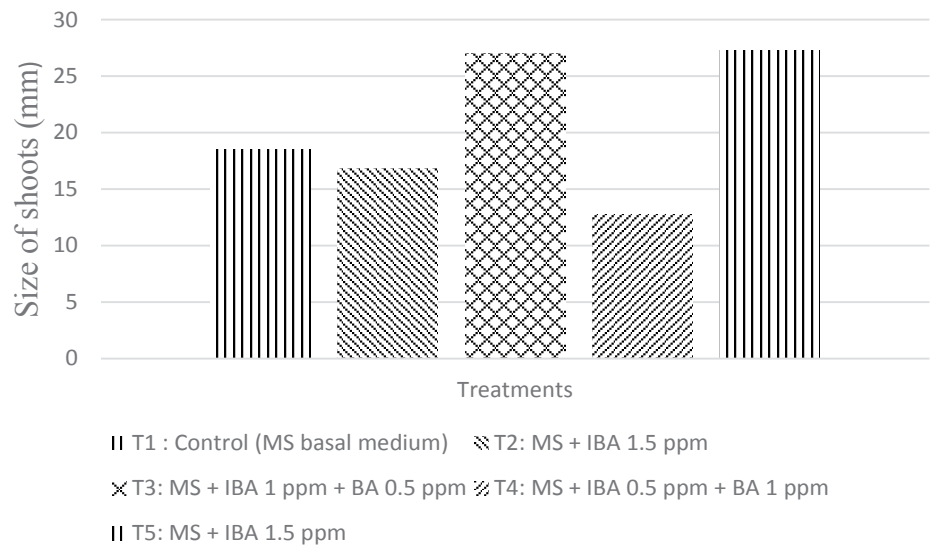

Figure 5: Effects of the BA-IBA and Kin-IBA treatments on the size of shoots of $C$. volcanica (values are expressed as percentages, $\mathrm{n}=18$ ) BA: Benzyladenine; IBA: indole butyric acid; ppm: parts per million

Figure 5 shows that the treatments with better effect on size length were the third $(27 \mathrm{~mm})$ and fifth $(27.25 \mathrm{~mm})$. There were significant differences $(\mathrm{p}<0.05)$ between treatments in the size of shoots produced.

As reported for the medicinal plants Tylophora indica and Rauvolfia tetraphylla (Faisal et al. 2012), the highest number of shoots per node and the best size of shoots were obtained with treatment 3 (MS + IBA 1 ppm + BA $0.5 \mathrm{ppm}$ ), thus it was selected as the proliferation culture medium.

Rooting stage. In this phase different combinations of NAA and IBA were tested because it has been described in many species that rooting induction is more effective when a combination of auxins is used rather than just one (George 1993).

Figure 6 shows that the best rooting treatment was T2 (MS + NAA 0.005 ppm and IBA 0.005 ppm), which produced $80 \%$ rooted plants (Fig. 1C). There were significant differences between treatments.

Al-Bahrany (2002) reported that in Citrus aurantifolia the best way of rooting was to use the combination of NAA 0.5mg / 1 + IBA 2mg / 1. Also Lewandowski (1991) determined NAA $0.001 \mathrm{mg} / 1+$ IBA $0.005 \mathrm{mg} / 1$ as the rooting medium for Vistis labrusca. The same growth regulator balance was used by Zhang et al. (2008) to root Phlox subulata.

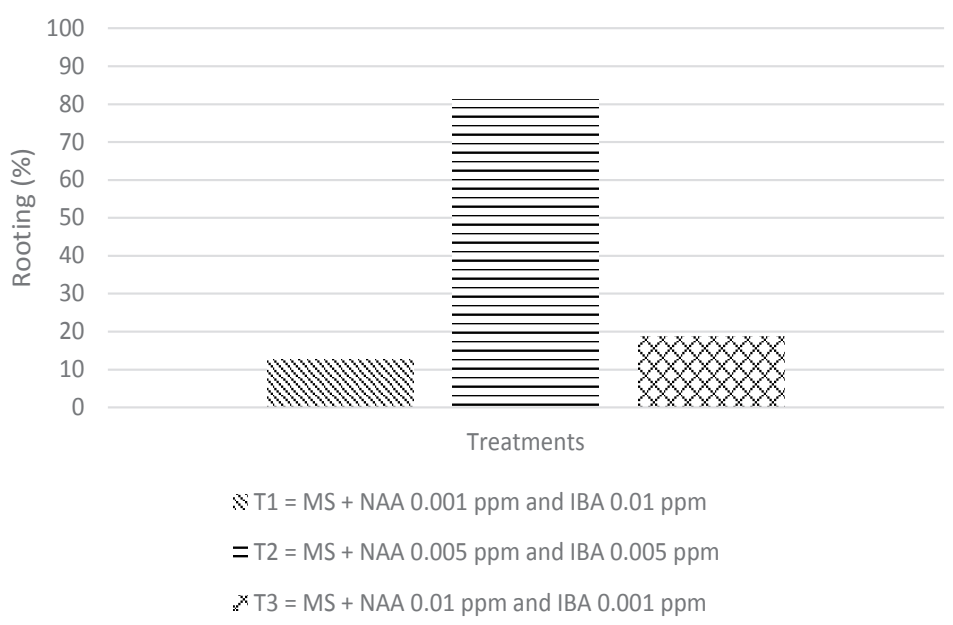

Figure 6: Effect of NAA-IBA treatments on the rooting of plants of $C$. volcanica (values expressed as percentages, $n=16$ ). NAA: naphthaleneacetic acid; IBA: indole butyric acid; ppm: parts per million 
Acclimatization. After 7 weeks of acclimatization (Fig. 1D) a survival ratio of $64.71 \%$ was obtained; this result is similar to the report of Zhang et al. (2008), who achieved 60\% acclimated plants in 90 days. Also Nava et al. (2011) described that $46.9 \%$ of Laelia eyermaniana plants were acclimatized in 90 days. Acclimatization is a long process, being the result of poor photosynthesis due to the unsuitable conditions of growth (Pierik, 1987). In addition, during the acclimatization process the plants must adequately regulate water absorption, translocation and transpiration processes, which make the adaptation longer and more delicate (Hurtado and Merino 1987).

\section{Conclusions}

The objective of this study was to establish a protocol for micropropagation of C. volcanica. The
$1 / 2$ MS medium (decreased to half concentration) was determined as the explant establishing medium. The best medium for shoot proliferation was MS + IBA $1 \mathrm{ppm} / 1$ + BA 0.5 ppm. Determined as best rooting medium, MS + ANA 0.005 ppm + AIB 0.005 ppm obtained 65\% survival after acclimatization.

\section{Acknowledgements}

Financial support was provided by National Universidad Nacional de San Agustín de Arequipa through Cienci Activa with contract $\mathrm{N}^{\circ} \mathrm{TT}-0016-2016$. We sincerely thank Mg. Luis Martínez Manchego of National University of San Agustin for his guidance in the statistical analysis of this investigation. We also recognize the lab assistance of Patricia Viveros Flores and Ana Caldas Araujo.

\section{Literature Cited}

\section{Al-Bahrany, A.}

2002. Effect of phytohormones on in vitro shoot multiplication and rooting of lime Citrus aurantifolia (Christm.) Swing. Scientia Horticulturae, 95: 285-295.

Azofeifa, A.

2009. Problemas de oxidación y oscurecimiento de explantes cultivados in vitro. Revisión bibliográfica. Agronomia Mesoamericana, 20 (1): 153-175.

Faisal M.; Anis M.; Alatar A.

2012. Plant Tissue Culture. LAP LAMBERT Academic Publishing. Saarbrücken, Germany. 164 p.

George, E.

1993. Plant propagation by tissue culture. Part 1 the technology. Ed. Exegetics Limited. Somerset, UK. 574 p.

Hidayat, $\mathrm{O}$.

2011. The study of IBA, BAP and Kinetin Hormones Usage Towards The Buds Multiplications of Agarwood Plant (Gyrinops versteegii (Gilg)Domke) by In Vitro. The First International Conference of Indonesian Forestry Researchers (INAFOR) Bogor. 5-7 December, Bogor, Indonesia. pp. 756-762.

Hurtado, D.; Merino, M.

1987. Cultivo de tejidos vegetales. Ed. Trillas. México, México. $232 \mathrm{p}$.

Iriondo, J.

2001. Conservación de germoplasma de especies raras y amenazadas (revisión) Invest. Agr.: Prod. Prot. Veg., 16 (1): 5-24

Keshavachandran, R. y K.V. Peter.

2008. Plant Biotechnology, Methods in Tissue Culture and Gene Transfer. Universities Press. Hyderabad, India. 299 p.

Lewandowski, V.

1991. Rooting and Acclimatization of Micropropagated Vitis labrusca 'Delawaare'. HortScience, 26 (5): 586-589.
Murashige, T.; Skoog, F.

1962. A revised médium for rapid growth and bioassays with tobacco tissues cultures. Physiol. Plant., 15: 473-479.

Nava, J.; Jiménez, A.; De Jesús, A.; Arenas, M.; Ventura, E.; Evangelista, S.

2011. Estudio de la morfología y aclimatación de plantas de Laelia eyermaniana RCHB. F. Generadas in vitro. Rev. Polibotánica, 32: 107-117.

Negrin, V.; Zalba, S.

2012. Descripción de la cipsela y de la plántula de Grindelia ventanensis (Asteraceae), especie endémica con potencial ornamental. Rev FCA UNCUYO, 44 (1): 13-25.

Olesen, M.; Fonnesbech, M.

1975. Phox plants from shoot tips. Acta Horticulturae 54: 95-99

Parveen, S.; Shahzad, A.

2014. Micropropagation and Conservation: Tissue Culture Approaches for Propagation and Conservation of a Highly Medicinal Legume: Senna sophera (Linn.) Roxb. Scholars Press. Saarbrücken, Germany. 239 p.

Porter, J.; Prather, L.

2008. Cantua dentritica (Polemoniaceae) a new species from Peru, and two new Cantua names. Rev. Aliso, 25: 31-35

Rahman, M.; Sultana, R.; Amin, M.

2012. Proliferation of Indian olive using tissue culture techniques. LAP LAMBERT Academic Publishing. Saarbrücken, Germany. $101 \mathrm{p}$.

Ranganathan, K.; Uthayasooriyan, M.

2016. Plant Tissue Culture. LAP LAMBERT Academic Publishing. Saarbrücken, Germany. 116 p.

Zhang, Z.; Dai, H.; Xiao, M.; Liu, X.

2008. In vitro induction of tetraploids in Phlox subulata $\mathrm{L}$. Rev. Euphytica, 159: 59-56 